\title{
THERMAL CHARACTERIZATION OF MONTMORILLONITE CLAYS SATURATED WITH VARIOUS CATIONS
}

\author{
V. Balek ${ }_{-}^{1,2^{*}}$, M. Beneš ${ }^{1}, J . ~ S ̌ u b r t^{2}$, J. L. Pérez-Rodríguez ${ }^{3}$, \\ P.E. Sánchez-Jiménez ${ }^{3}$, L. A. Pérez-Maqueda ${ }^{3}$, J. Pascual-Cosp ${ }^{4}$ \\ ${ }^{1}$ Nuclear Research Institute Řež, plc., CZ-250 68 Řež, Czech Republic \\ ${ }^{2}$ Institute of Inorganic Chemistry ASCR, CZ-250 68 Řež, Czech Republic \\ ${ }^{3}$ Institute of Materials Sciences, CSIC - Univ. of Sevilla, 41092 Sevilla, Spain \\ ${ }^{4}$ Department of Civil Engineering, Technology and Materials, Univ of Málaga, \\ 29013 Málaga, Spain
}

\begin{abstract}
Emanation thermal analysis (ETA), thermogravimetry and high temperature XRD were used to characterize the thermal behavior during dehydration of natural $\mathrm{Na}$ montmorillonite (Upton Wyoming, USA) and homoionic montmorillonite (MMT) samples saturated with different cations, i.e. $\mathrm{Cs}^{+}, \mathrm{NH}_{4}{ }^{+}, \mathrm{Li}^{+}, \mathrm{Al}^{3+}$ and $\mathrm{Mg}^{2}$. ETA results characterized microstructure changes that accompanied the mass loss of the samples due to dehydration on heating in air .A collapse of interlayer space between the silicate sheets after water release from the MMT samples was characterized by a decrease of the radon release rate, $\Delta \mathrm{E}$. Decreases in c-axis basal spacing $\left(d_{001}\right)$ values determined from XRD patterns for the different montmorillonite samples follow the sequence:

Mg-MMT $>$ Al -MMT $>$ Li $-M M T>$ Na-MMT $>$ NH$_{4}-\mathrm{MMT}>$ Cs-MMT.

The decrease of the radon release rate $(\Delta \mathrm{E})$ determined by ETA that characterized microstructure changes due to collapse of interlayer space corresponded well to differences in the c-axis basal spacing $\left(\Delta \mathrm{d}_{001}\right)$ values determined from the XRD patterns before and after samples dehydration .

*corresponding author: bal@ujv.cz
\end{abstract}


Key words: Na-montmorillonite saturated with various cations, emanation thermal analysis, $\mathrm{XRD}$, thermogravimetry , microstructure changes , dehydration

\section{Introduction}

In order to understand the environmental behaviour of monmorillonite clay minerals their dehydration and dehydroxylation on heating has been studied by several authors [1-7]. It was found that differences in the montmorillonite dehydration are due to a more or less strong polarising power of the exchangeable cation. The hydration number of the exchangeable cations can be expressed by a basic spacing of the clay structure characterized by c-axis basal spacing $\mathrm{d}_{001}$ [1]. The decrease of the c-axis basal spacing takes place as the result of the montmorillonite dehydration, observed usually on heating up to $200{ }^{\circ} \mathrm{C}$. Mackenzie [5] suggested that the amount of interlayer water depends on hydration energy of the adsorbed cations and on hydration of the surface, and that thermogravimetry results can be interpreted to give relative values for these amounts of water. He stated that for most of divalent cations (e.g. $\mathrm{Mg}^{2+}$ and $\mathrm{Ca}^{2+}$ ) the ion is more important that the interlayer surface, but for larger divalent cations as well as for monovalent cations the influence of the layered surface on the hydration is dominant. Glasser et al. [7] showed that polyvalent ions tend to detach themselves from the silicate surface and incorporate in the water layers. They stated that the complete loss of the interlayer water is accompanied by a reduction in the c-axis dimensions (to 9.4-10 $\AA$ ) with exact value depending on the size of interlamellar ions.

In this study thermogravimetry, emanation thermal analysis and high temperature X- ray diffraction methods were used to characterize the thermal behavior during dehydration of natural $\mathrm{Na}$ montmorillonite and homoionic montmorillonite samples prepared 
by a saturation of $\mathrm{Na}$ montmorillonite with cations of $\mathrm{Cs}^{+}, \mathrm{NH}_{4}^{+}, \mathrm{Li}^{+}, \mathrm{Al}^{3+}$ and $\mathrm{Mg}^{2+}$, respectively . High temperature $\mathrm{X}$ - ray diffraction was used to determine the c-axis basal spacing parameters of the montmorillonite samples. Emanation Thermal Analysis (ETA) $[8,9]$, based on the measurement of radon release from samples previously labeled, was used to characterize microstructure changes during, in situ“ heating of the samples. The ETA has been previously used in the characterization of the thermal behavior of various minerals, such as kaolinite [10], saponite, beidelite [3], vermiculite [11-13], boehmite [14], pyrophyllite, talc [15], brannerite [16], haematite [17].

\section{Experimental}

\subsection{Samples}

Natural Na-montmorillonite (Upton, Wyoming, USA) was used as a starting material. Homoionic montmorillonite samples saturated with $\mathrm{Cs}^{+}, \mathrm{NH}_{4}^{+}, \mathrm{Li}^{+}, \mathrm{Al}^{3+}$ and $\mathrm{Mg}^{2+}$,respectively, were prepared from Na-montmorillonite sample as follows: the amount of $10 \mathrm{~g}$ of the Na-montmorillonite was mixed with $800 \mathrm{ml}$ of water and stirred during two days. After decantation $0.2 \mathrm{M}$ chloride solution $(200 \mathrm{ml})$ of the respective cation was added. The suspension was stirred for two days, several times washed by distilled water until the negative reaction for chlorides (using $\mathrm{Ag}^{+}$ions). The samples prepared by this way were dried at the temperature of $40{ }^{\circ} \mathrm{C}$ in air .

\subsection{Methods}

Emanation thermal analysis (ETA) measurements were carried out by using a modified NETZSCH Equipment Type DTA 404. The samples were heated at the rate of 6 $\mathrm{K} / \mathrm{min}$ in a constant air flow of $75 \mathrm{ml} / \mathrm{min}$. Samples for ETA measurements were labeled by a surface adsorption of trace amount of ${ }^{228} \mathrm{Th}$ as nitrate in acetone solution. The specific activity of the sample was $10^{4} \mathrm{~Bq} / \mathrm{gram}$. Atoms of radon ${ }^{220} \mathrm{Rn}$ were formed by a spontaneous 
$\alpha$-decay of ${ }^{228} \mathrm{Th}$ and ${ }^{224} \mathrm{Ra}$. The ${ }^{220} \mathrm{Rn}$ atoms were implanted into the subsurface of the samples by recoil energy of $85 \mathrm{keV} /$ atom to a maximum depth of $80 \mathrm{~nm}$, as calculated by the Monte Carlo method using TRIM code [18]. More details about emanation thermal analysis as a less common method are given elsewhere $[8,9]$. TG/DTG measurements were carried out by using NETZSCH Equipment Type STA 429 on heating at $6 \mathrm{~K} / \mathrm{min}$ in air. XRD equipment (PHILIPS PW 1050/25) using $\mathrm{Cu} \mathrm{K}_{\alpha}$ Ni-filtered radiation and equipped with a high temperature chamber was applied to obtain XRD patterns and to determine c-axis basal spacings $\left(\mathrm{d}_{001}\right)$.

\section{Results and discussion}

Thermogravimetry results (TG/DTG curves) of Na-montmotillonite and homoionic montmorillonite samples saturated with $\mathrm{Mg}^{2+}, \mathrm{Cs}^{+}, \mathrm{NH}_{4}^{+}, \mathrm{Li}^{+}$and $\mathrm{Al}^{3+}$ ions, respectively, are presented in Figs. 1 A-F. The mass loss observed from about $50{ }^{\circ} \mathrm{C}$ up to about $200{ }^{\circ} \mathrm{C}$ corresponds to a release of mainly interlayer water molecules situated between the silicate sheets of the montorillonite samples. Both the amount of released water and the temperature of the process is affected by the interlayer cation $[5,6]$. The dehydration of the samples produces a decrease in the basal spacing, as shown by high temperature XRD measurements ( see Figures 2 A-F ).

Figures 3 A-F depict emanation thermal analysis results of $\mathrm{Na}-$ montmorillonite and homoionic montmorillonite samples prepared by saturation of $\mathrm{Na}$-montmorillonite with $\mathrm{Mg}^{2+}, \mathrm{Cs}^{+}, \mathrm{NH}_{4}{ }^{+}, \mathrm{Li}^{+}$and $\mathrm{Al}^{3+}$ ions, respectively. These figures show an enhanced radon release rate, $\mathrm{E}(\mathrm{T})$, at the beginning of the heating due to the surface exposure after the water release from the samples, followed by a decrease of radon release rate that characterized the collapse of the interlayer space between the silicate sheets, initially filled by water molecules. 
By this way the ETA results brought about information about the structure changes under in situ heating of the montmorillonite samples during their dehydration .According to the ETA results presented in Figures 3 A-F the intensity of changes in the radon mobility differed for the ion-exchanged montmorillonite samples investigated. The results obtained in this study can be compared with the results of our previous study [4] characterizing thermal behaviour on argon heating of $\mathrm{Na}$ - monmorillonite saturated with cations of $\mathrm{Li}^{+}, \mathrm{Mg}^{2}$ or $\mathrm{Al}^{3}$, respectively.

In this study a special attention has been paid to the comparison of the ETA results with XRD results characterizing the collapse of the interlayer space during dehydration of the montmorillonite samples. A mathematical model proposed [19] was used in order to quantitatively evaluate the mobility of radon atoms that served as a probe of microstructure changes in the samples.

The temperature dependence of the radon release rate measured, $\mathrm{E}(\mathrm{T})$ can be expressed as

$$
E(T)=E_{25}+E_{D}(T) \cdot \Psi(T)
$$

where $E_{25}$ is radon release rate measured at room temperature, $E_{D}(T)$ is radon diffusion along structure irregularities that served as radon diffusion paths, $\Psi(T)$ is characterizing the changes in the number of the radon diffusion paths.

The temperature dependence of the radon release rate , $\mathrm{E}_{\mathrm{D}}(\mathrm{T})$, was used for the evaluation of the transport properties and of microstructure development characterization of the samples on heating.

The model curves of the temperature dependences of the radon release rate $E_{D}(T)$ are presented in Figures $3 \mathrm{~A}-\mathrm{F}$ as full lines, whereas the ETA experimental data are presented as points. A good agreement of the modelling results and the experimental ETA data was achieved. 
Fig. 4 depicts temperature dependences of $\Psi(T)$ functions obtained by modelling and fitting the experimental ETA data with the mathematical model [19] to characterize the intensity of the microstructure changes of the initial montmorillonite interlayer structure due to dehydration. Table 1 summarizes values of radon release rate decrease $(\Delta \mathrm{E})$. From Fig.4 and Table 1 it follows that the $\Delta \mathrm{E}$ values that characterized sticking of the montmorillonite interlayer space due to dehydration decrease in the sequence:

Mg-MMT $>$ Al $-\mathrm{MMT}>\mathrm{Li}-\mathrm{MMT}>\mathrm{Na}-\mathrm{MMT}>\mathrm{NH}_{4}-\mathrm{MMT}>\mathrm{Cs}-\mathrm{MMT}$.

Values of difference in c-axis basal spacing $\left(\Delta \mathrm{d}_{001}\right)$ that characterize the sticking of the interlayer space of the samples due to their dehydration are also included in Table 1.

Fig. 5 depicts the linear relationship between values of the differences $\Delta \mathrm{d}_{001}$ in values of caxis basal spacing and the corresponding values of $\Delta \mathrm{E}$ characterizing microstructure changes due to dehydration of the montmorillonite samples. The most intense decrease of the radon mobility, $\Delta \mathrm{E}$, was observed with the Mg-montmorillonite ( see Fig. $1 \mathrm{~B}$ and Fig. 4. curve 2). The differences in the c-axis basal spacing $\left(\Delta \mathrm{d}_{001}\right)$ determined from the XRD patterns ( see Fig.2 B) supported these results. Thus, it is obvious that the ETA characterization of the microstructure changes due to dehydration of the samples, corresponded well to differences in the c-axis basal spacing $\left(\Delta \mathrm{d}_{001}\right)$ values determined from the XRD patterns.

\section{Conclusions}

ETA brought about additional information about processes that took place on heating of homoionic montmorillonite samples saturated with various cations .

The decrease of radon release rate $\Delta \mathrm{E}$, determined by ETA characterized a decrease of radon mobility during the collapse of the samples interlayer space. A good agreement was found between the decrease of radon release rate, $\Delta \mathrm{E}$ determined from ETA measurements and differences $\Delta \mathrm{d}_{001}$ in values of the c-axis basal spacing $\left(\mathrm{d}_{001}\right)$ determined from XRD patterns. 


\section{Acknowledgments}

The paper was prepared in the frame of the bilateral cooperation between C.S.I.C and Academy of Sciences of the Czech Republic. Presentation of this work was supported by the Ministry of Education of Czech Republic (Project LA-292).and by the Ministry of Education of Spain (MAT2004-02640)

\section{References}

1. R.A. Rowland, E.J. Weiss, W.D. Bradley, Nat. Acad. Sci. Publ., 456 (1956) pp. 85-96.

2. C.M. Warshaw, P.E. Rosenberg, R. Roy, Clay Minerals Bull., 4 (1960) 113.

3. Z. Málek, V. Balek, D. Garfinkel-Shweky and S. Yariv, J. Thermal Anal., 48 (1997) 83.

4. V. Balek, M. Beneš, G. Matuschek, A.A.Kettrup, Z.Málek, J. Therm. Anal. Cal., 88 (2007) 93

5. R.C. Mackenzie, Ber. Deut. Keram. Ges., 41 (1964) 696.

6. C.M. Earnest, in: W. Smykatz-Kloss and Slade S.J. Warne (Eds), Thermal Analysis in Geosciences, Springer Verlag 1991, pp. 288-312

7. R.I. Glasser, I. Mantin, J. Mering, Intern. Geol. Congr. 21st Session, Norden, France (1960) pp. 28-34.

8. V. Balek and J. Tölgyessy, Emanation thermal analysis and other radiometric emanation methods, in: Wilson and Wilson (Eds), Comprehensive Analytical Chemistry, Part XIIC, Elsevier, Amsterdam 1984, 304 pp.

9. V. Balek, J. Šubrt, T. Mitsuhashi, I. N. Beckman and K. Györyová, J. Therm. Anal. Cal., $67(2002) 15$

10. V.Balek, M Murat, Thermochim, Acta, 282 /283 (1996) 385 
11. L. A. Pérez-Maqueda, V.Balek, J. Poyato, J. L Pérez-Rodríquez, J.Šubrt, I.M. Bountseva, I. N. Beckman and Z. Málek, J. Therm. Anal. Cal., 71 (2003) 715.

12. J. Poyato, L. A. Perez-Maqueda, A. Justo, V. Balek, Clays Clay Miner. 50 (2002) 791.

13. V. Balek, J. L. Perez-Rodriguez, L. A. Perez-Maqueda, J. Subrt, J. Poyato, J. Therm. Anal. Cal. 88 (2007) 819.

14.V.Balek,J.Šubrt,J.Rouquerol,P.Llewellyn,V.Zelenák,I.M.Bountseva,I.N.Beckman, K.Györyová, J.Therm. Anal.Cal., 71(2003) 773

15. V. Balek, L.A. Pérez-Maqueda, J. Poyato, Z. Černý, V. Ramírez-Valle , I.M.Bountseva, J. L. Pérez-Rodríguez, J. Therm. Anal. Cal., 88 (2007) 87

16.V. Balek, E.R. Vance, V. Zeleňák, Z. Málek, J. Šubrt, J. Therm. Anal. Cal., 88 (2007) 93

17. L. A. Pérez-Maqueda, J. M. Criado, C. Real, V. Balek, J. Subrt, J. Europ. Ceram. Soc. 22 (2002) 2277.

18. J.F. Ziegler and J.P.Biersack, The stopping and range of ions in solids, Pergamon Press, New York ,1985.

19. I.N.Beckman, V. Balek, J. Therm. Anal. Cal., 67 (2002) 49 


\section{Table 1}

Values of radon release rate decrease $\Delta \mathrm{E}$ and differences c-axis basal spacing $\Delta \mathrm{d}_{001}$ characterizing dehydration of montmorillonite samples saturated with various cations

\begin{tabular}{|c|c|c|}
\hline Montmorillonite & Decrease of radon release rate & Difference in c-axis spacing \\
\hline Cation & $\Delta \mathbf{E}$ [rel.units] & $\Delta \mathbf{d}_{\mathbf{0 0 1}}[\mathbf{\AA}]$ \\
\hline Initial sample- & 0.149 & 1.59 \\
$\mathbf{N a}^{+}$ & & \\
\hline $\mathbf{M g}^{2+}$ & 0.349 & 4.48 \\
\hline $\mathbf{C s}^{+}$ & 0.064 & 0.94 \\
\hline $\mathbf{N H}^{+}$ & 0.100 & 1.37 \\
\hline $\mathbf{A l}^{\mathbf{3}^{+}}$ & 0.276 & 3.80 \\
\hline $\mathbf{L i}^{+}$ & 0.257 & 2.57 \\
\hline
\end{tabular}




\section{Captions to figures}

Figs. 1 A-E

Thermogravimetry results of montmorillonite samples measured in air at the rate $6 \mathrm{~K} / \mathrm{min}$.

(A) : Na-montmorillonite- natural sample ( locality Upton, Wyoming, USA),

(B): $\mathrm{Mg}^{2+}$ - exchanged montmorillonite ,(C): $\mathrm{Cs}^{+}$- exchanged montmorillonite ,

(D): $\mathrm{NH}_{4}{ }^{+}$-exchanged montmorillonite, (E): $\mathrm{Al}^{3+}$-exchanged montmorillonite,

(F): $\mathrm{Li}^{+}$-exchanged montmorillonite

\section{Figs.2 A-E}

High temperature XRD patterns obtained on heating of the montmorillonite samples
(A) : Na-montmorillonite- natural sample ( locality Upton, Wyoming, USA),
(B): $\mathrm{Mg}^{2+}$ - exchanged montmorillonite ,(C): $\mathrm{Cs}^{+}$- exchanged montmorillonite,
(D): $\mathrm{NH}_{4}{ }^{+}$-exchanged montmorillonite, (E): $\mathrm{Al}^{3+}$-exchanged montmorillonite,
(F): $\mathrm{Li}^{+}$-exchanged montmorillonite

\section{Figs.3 A-F}

ETA results of Montmorillonite samples measured on heating in air at the rate $6 \mathrm{~K} / \mathrm{min}$.
(A) : Na-montmorillonite- natural sample ( locality Upton, Wyoming, USA),
(B): $\mathrm{Mg}^{2+}$ - exchanged montmorillonite ,(C): $\mathrm{Cs}^{+}$- exchanged montmorillonite,
(D): $\mathrm{NH}_{4}{ }^{+}$-exchanged montmorillonite, (E): $\mathrm{Al}^{3+}$-exchanged montmorillonite,
(F): $\mathrm{Li}^{+}$-exchanged montmorillonite

\section{Fig.4}

Temperature dependences of $\Psi_{\mathrm{i}}(\mathrm{T})$ functions characterizing collapse of the interlayer space between the silicate sheets due to dehydration of the montmorillonite samples

(1) : Na-montmorillonite- natural sample ( locality Upton, Wyoming, USA),

(2): $\mathrm{Mg}^{2+}$ - exchanged montmorillonite, (3): $\mathrm{Cs}^{+}$- exchanged montmorillonite,

(4): $\mathrm{NH}_{4}{ }^{+}$-exchanged montmorillonite , (5): $\mathrm{Al}^{3+}$-exchanged montmorillonite, 
(6): $\mathrm{Li}^{+}$-exchanged montmorillonite

\section{Fig.5}

Relationship between values of differences $\left(\Delta \mathrm{d}_{001}\right)$ in c-axis basal spacing determined from $\mathrm{XRD}$ patterns and corresponding changes of the radon release rate $(\Delta \mathrm{E})$ determined from ETA measurements during samples dehydration. 

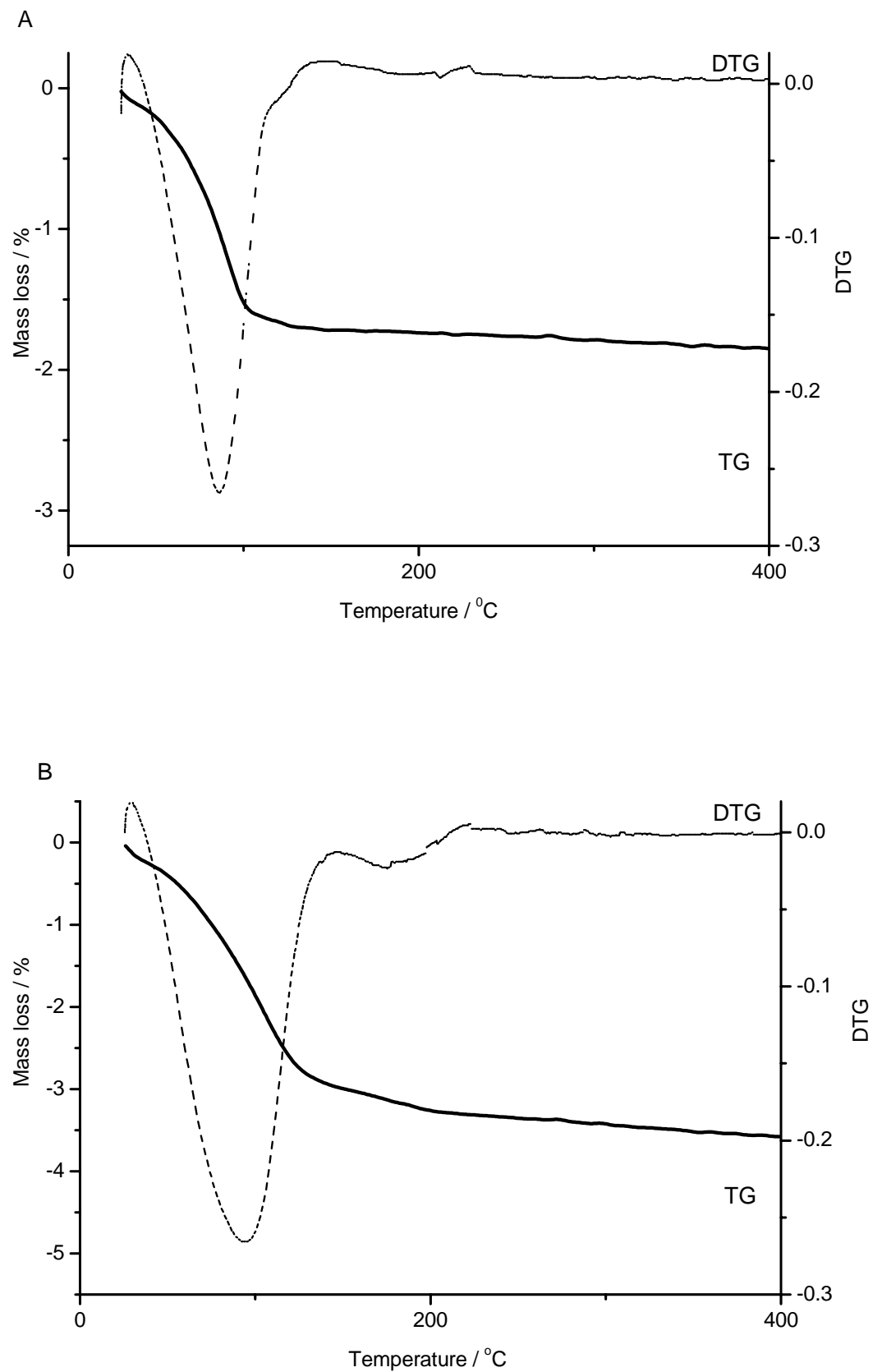

Fig.1A-B 

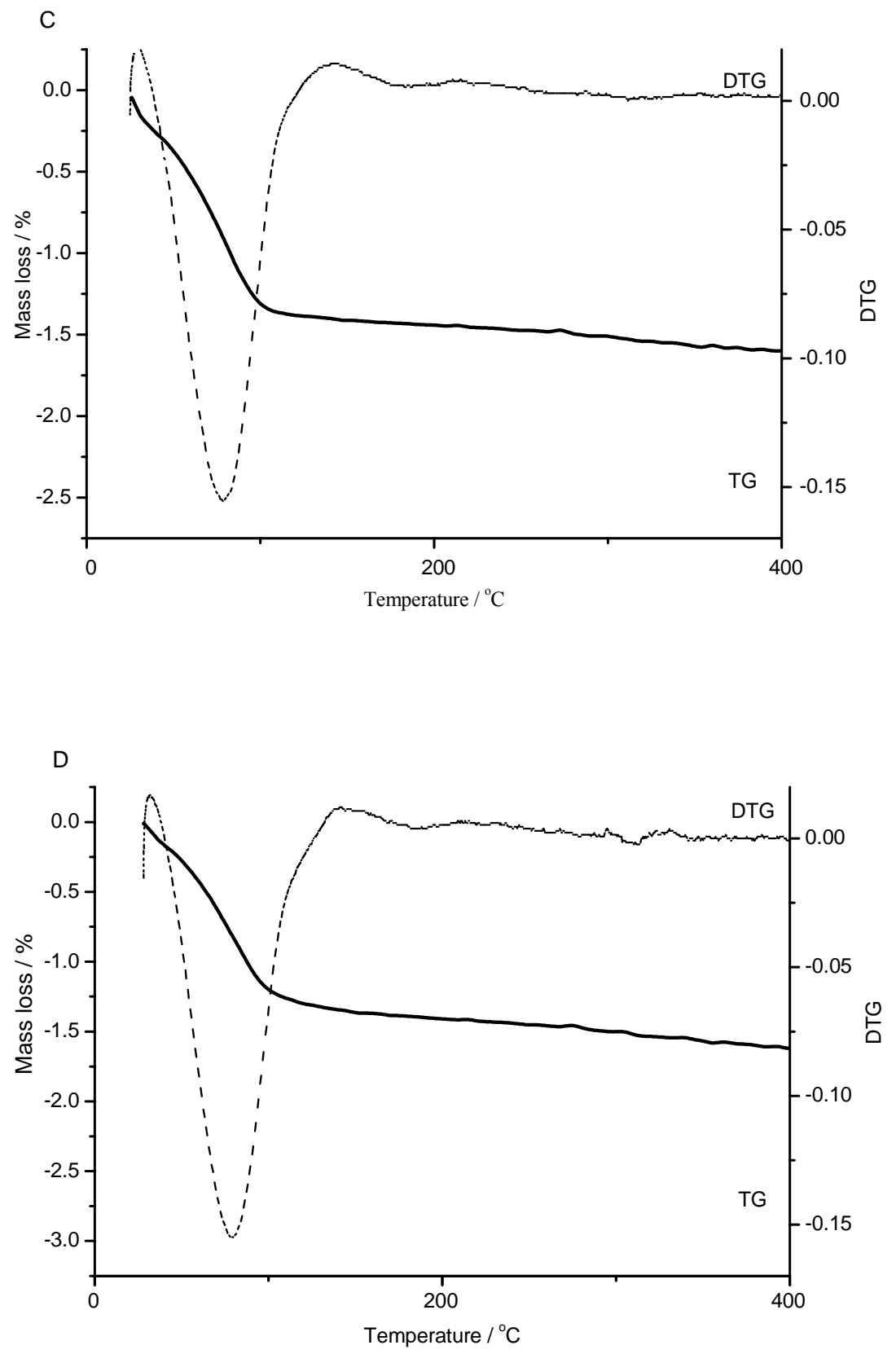

Fig. 1C-D 

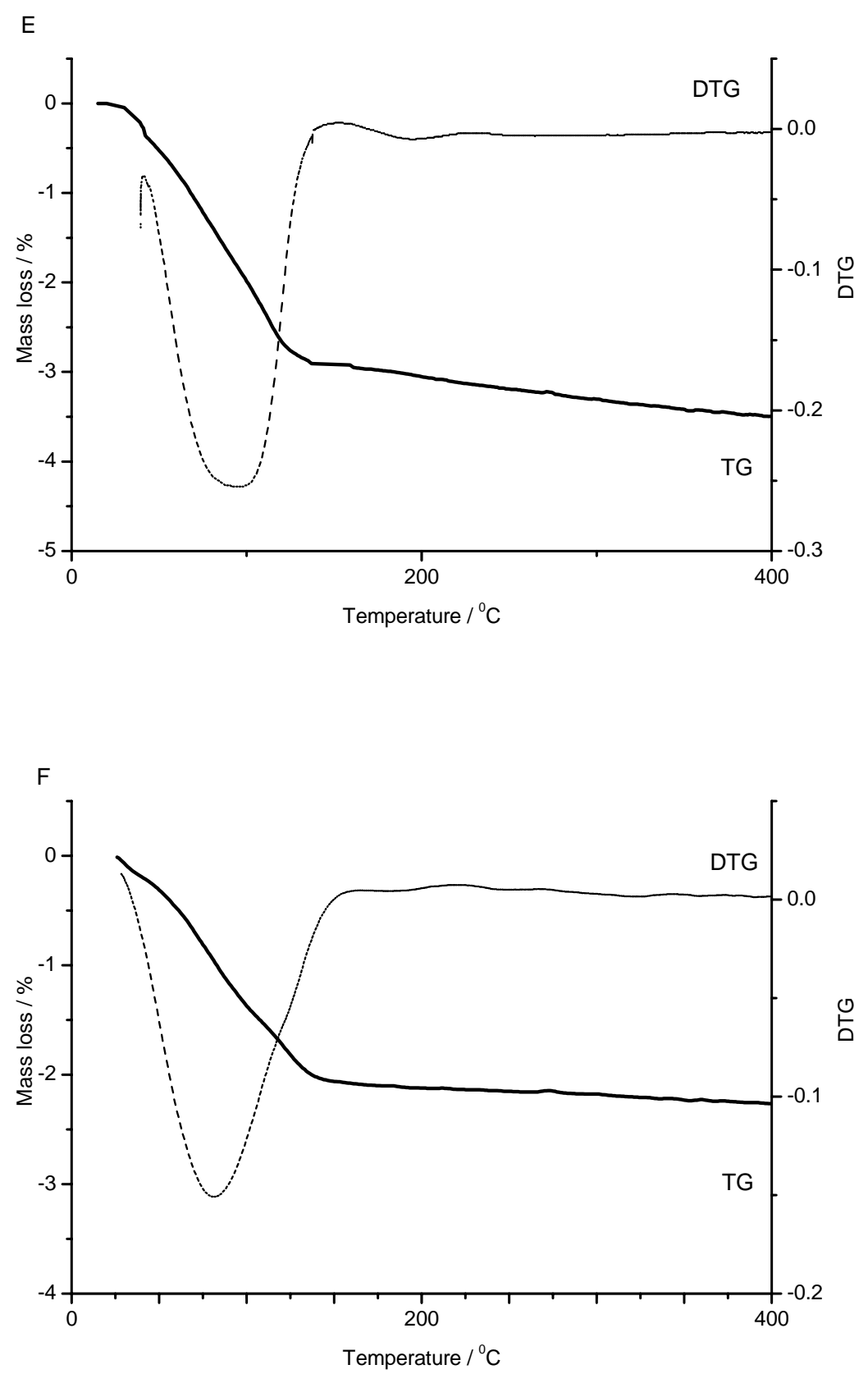

Balek et al,

Figs. 1 E-F 

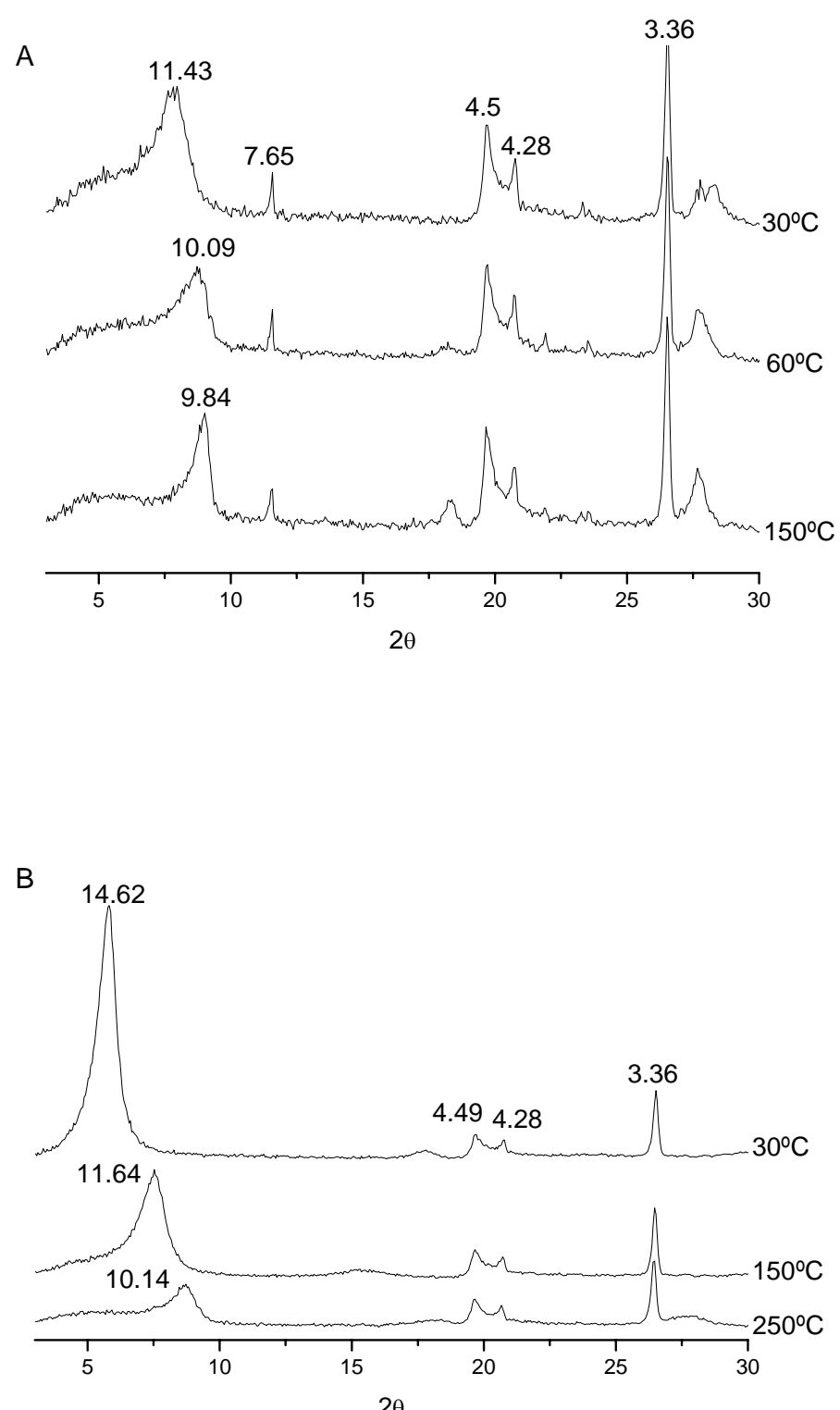

Fig. 2A-B 

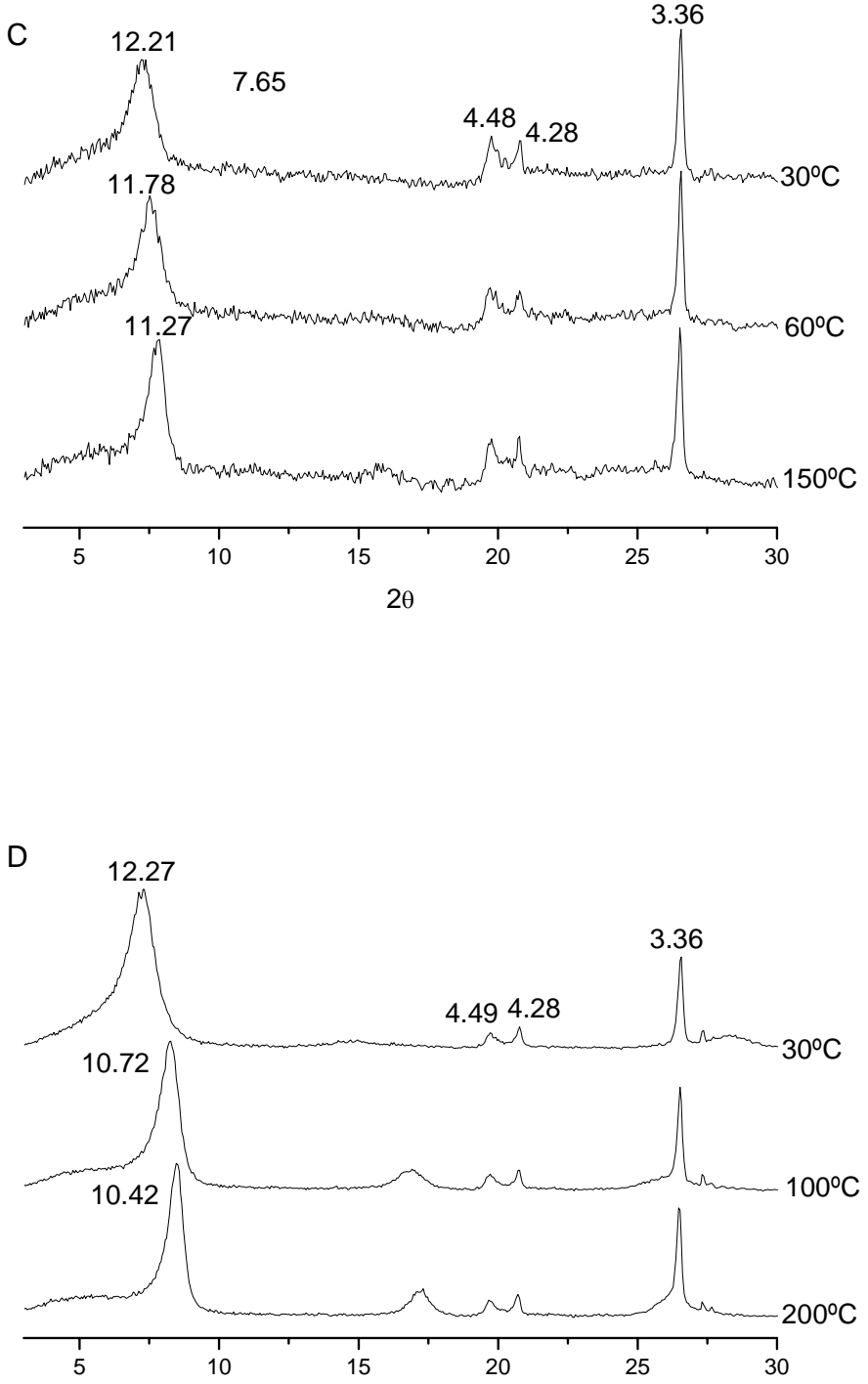

$2 \theta$

Fig. 2C-D 

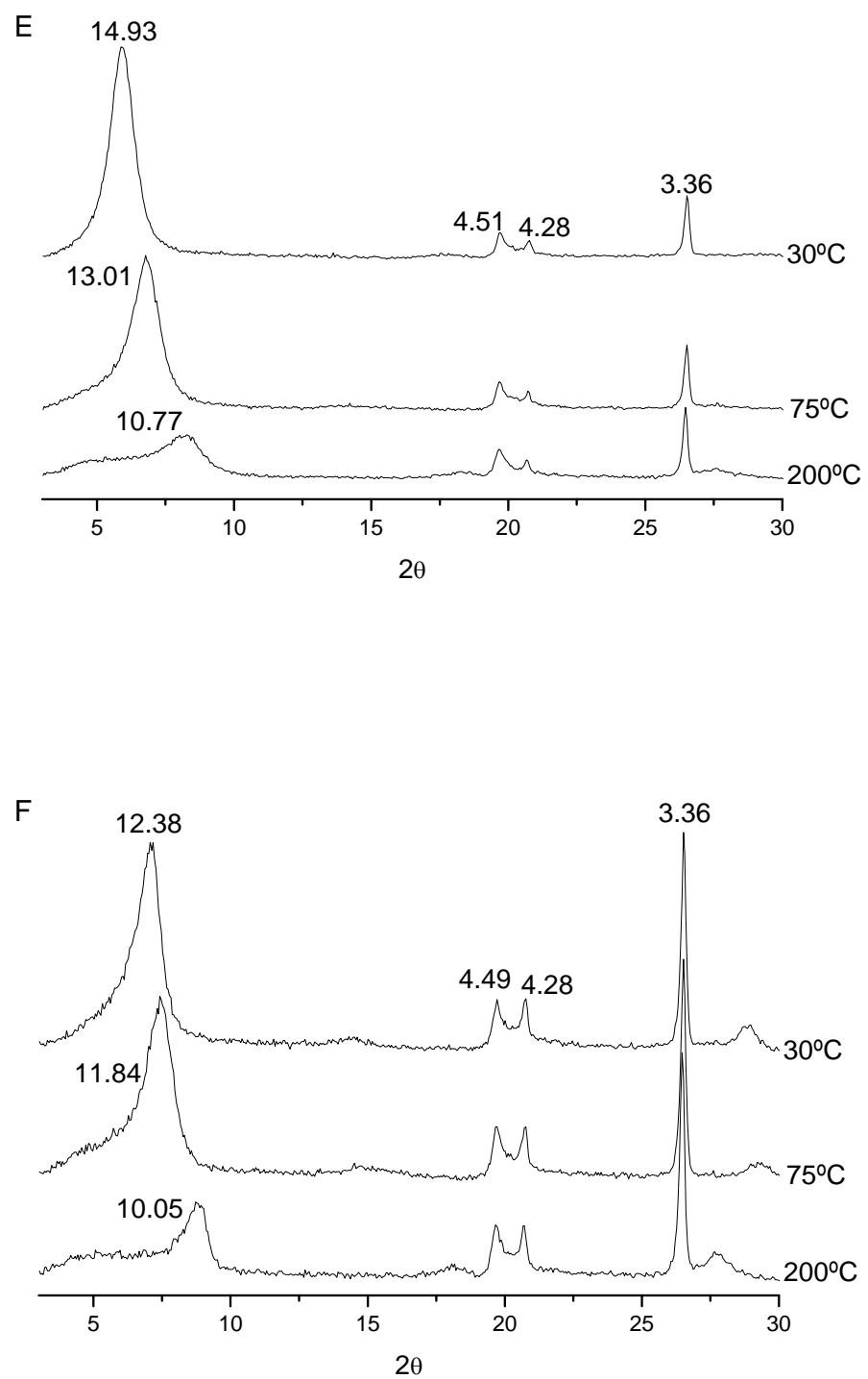

Balek et al,

Figs. 2 E-F 

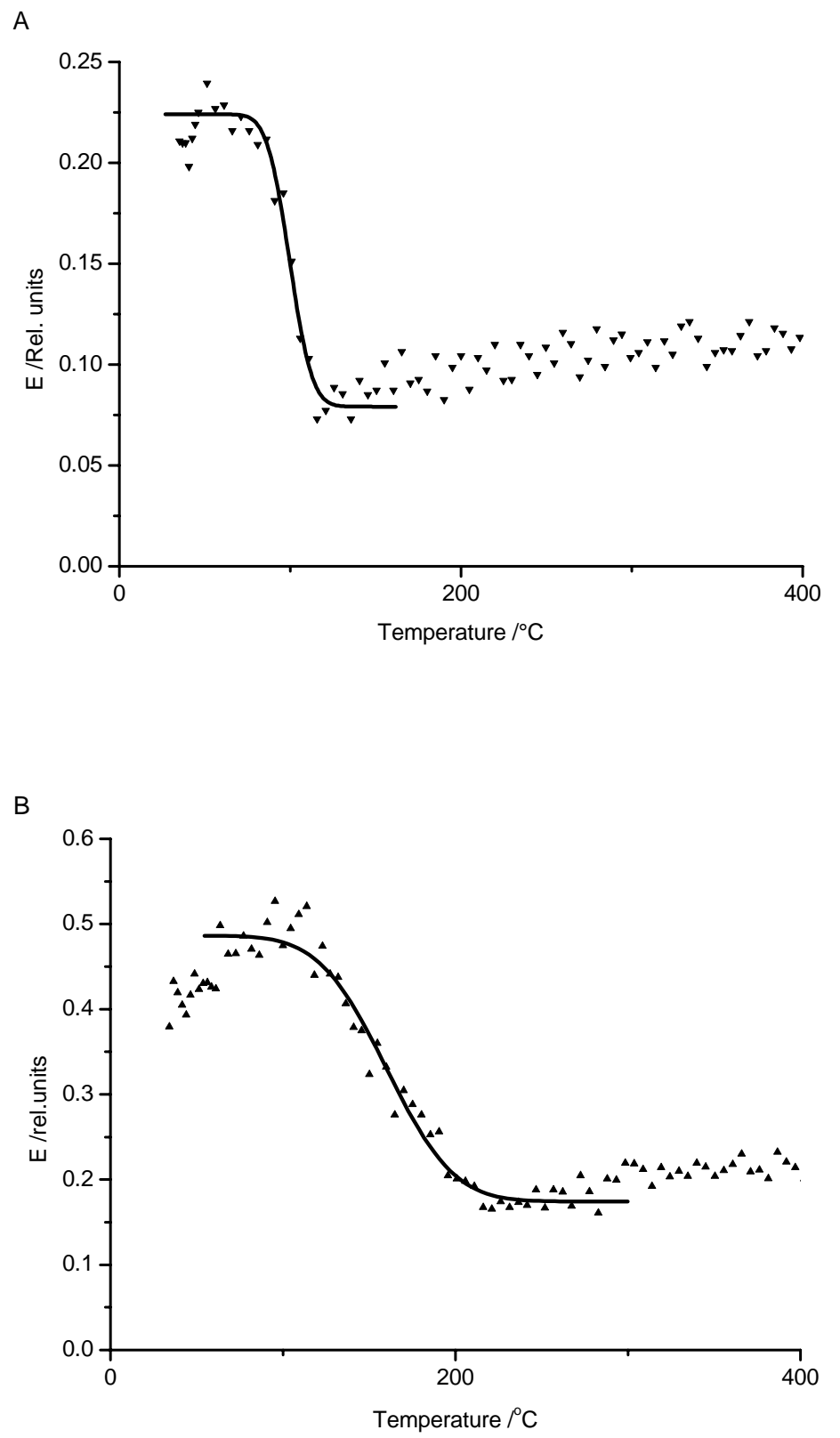

Fig.3A-B 


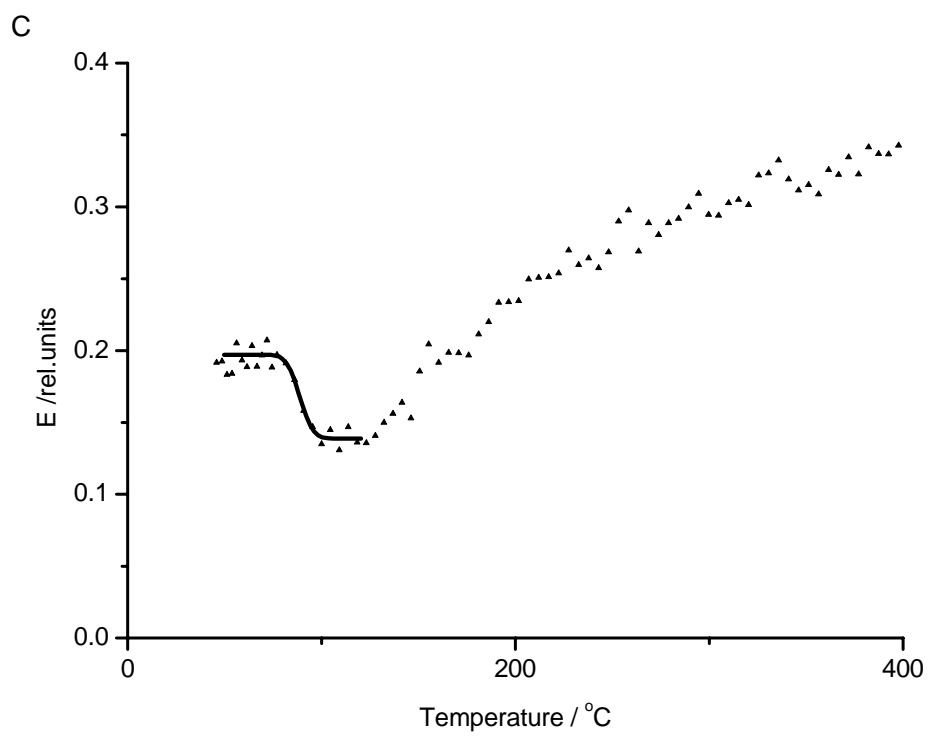

D

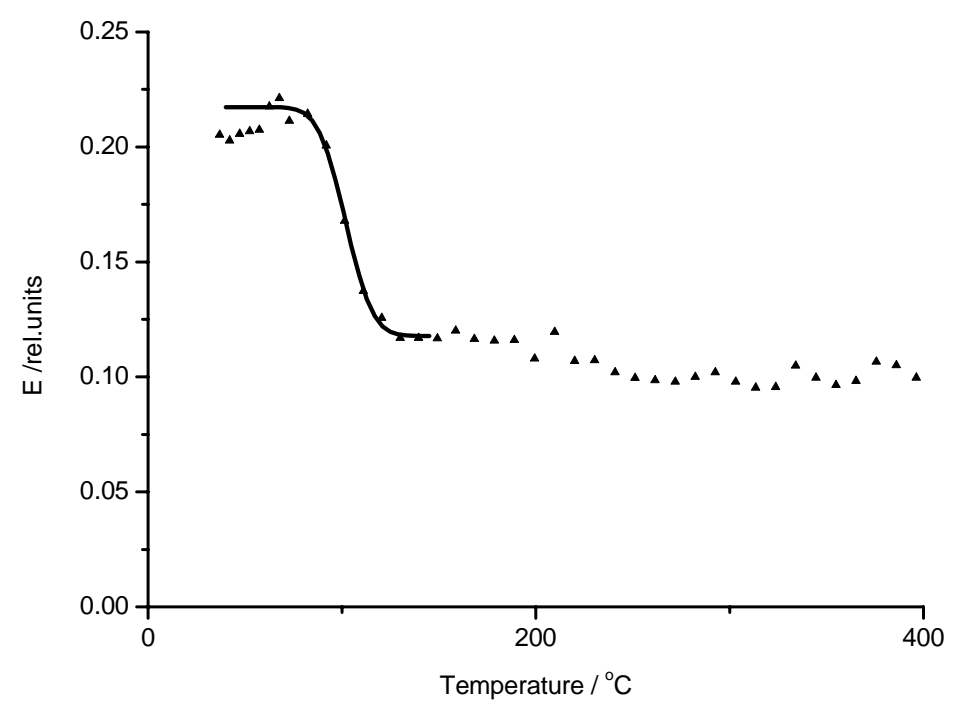

Fig.3C-D 

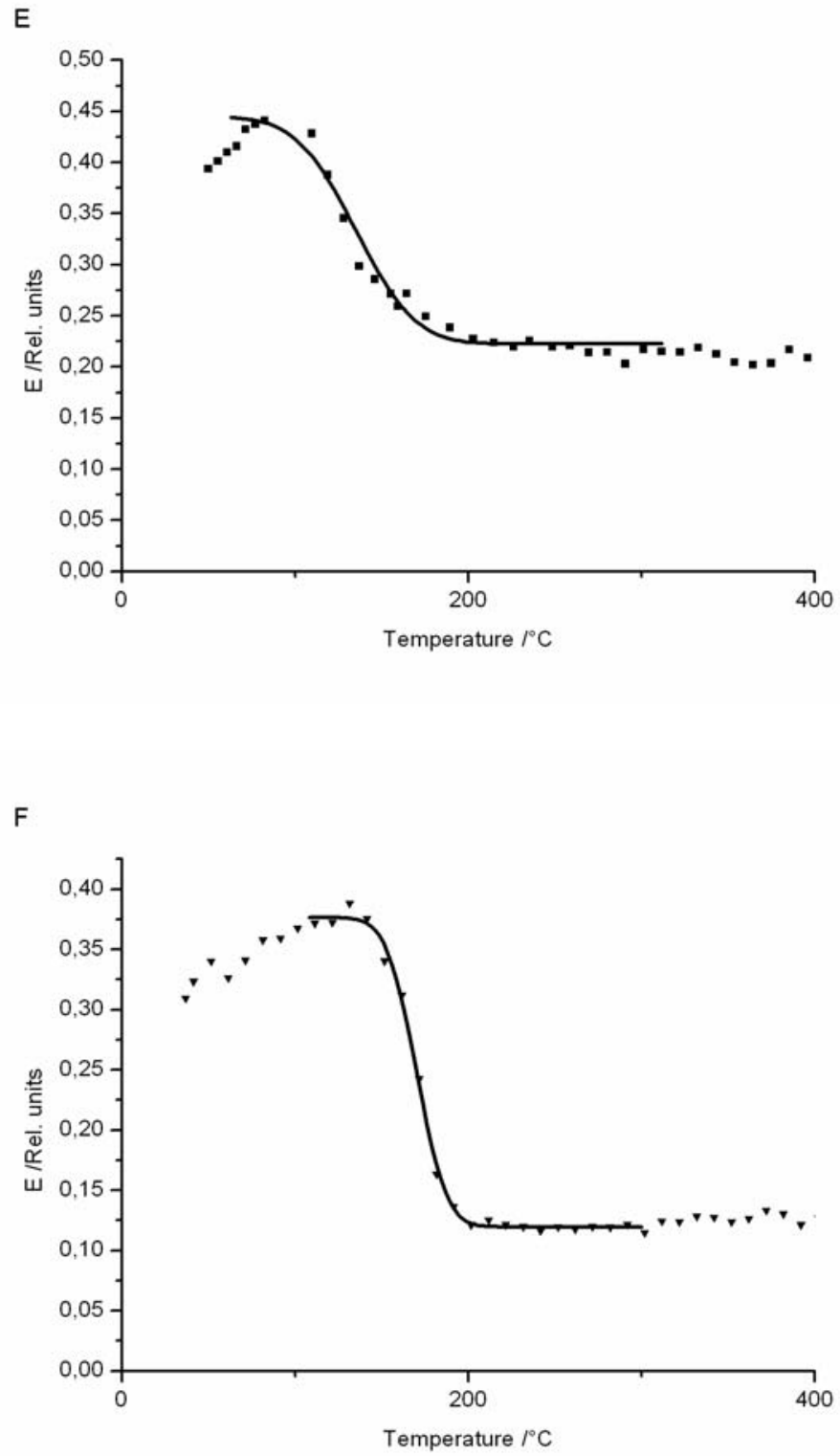

Balek et al

Figs.3 E-F 


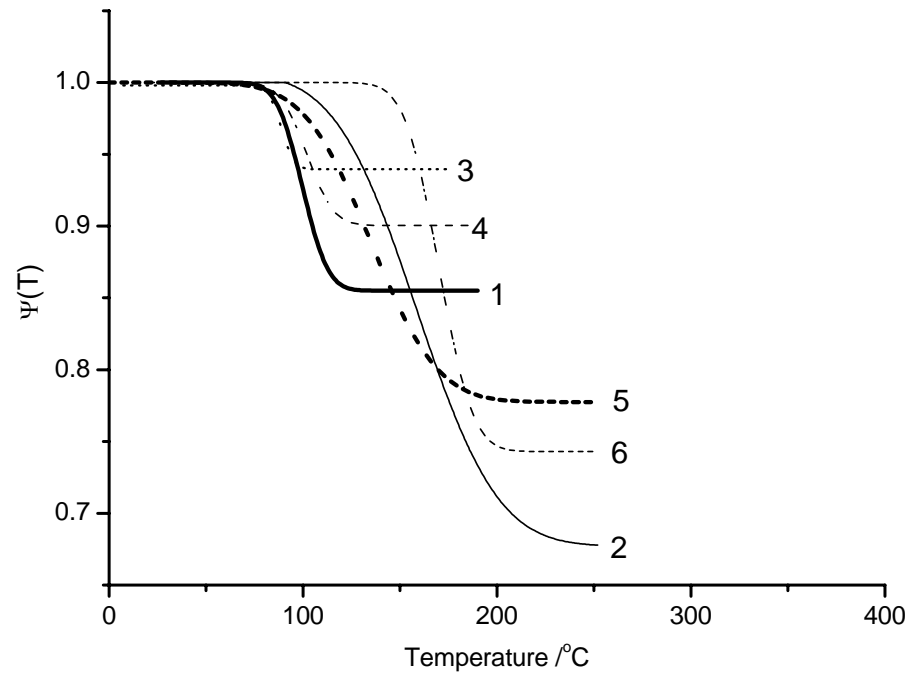

Balek et al

Fig.4 


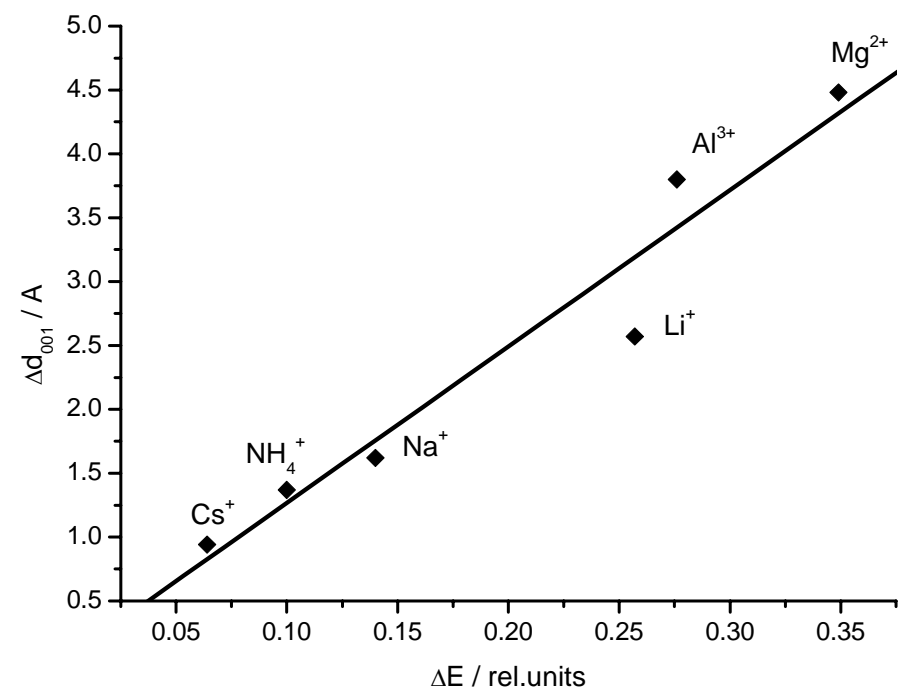

Balek et al

Fig.5 